Zeynep Oktuğ $\breve{a}^{*}$

${ }^{a}$ Doç. Dr., İstanbul Kültür Üniversitesi, Fen-Edebiyat Fakültesi, Psikoloji Bölümü, 34158, İstanbul/Türkiye.

ORCID: 0000-0002-8021-9074

\section{MAKALE BILGISII}

Makale Geçmişi:

Başvuru tarihi: 15 Ağustos 2018

Düzeltme tarihi: 12 Şubat 2019

Kabul tarihi: 24 Şubat 2019

Anahtar Kelimeler:
Başarılı Mizah,
Başarısız Mizah,
Özgüven
Yeterlilik

\section{ARTICLE INFO}

\section{Article history:}

Received 15 August 2018

Received in revised form 12 February 2019

Accepted 24 February 2019

\section{Keywords:}

Successful Humor,

Unsuccessful Humor,

Self-confidence,

Competence.
ÖZ

$\mathrm{Bu}$ araştırma, başarılı ve başarısız mizahın etkilerinin, algılanan özgüven ve yeterlilik açısından incelenmesi amacıyla gerçekleştirilmiştir. Başarılı ve başarısız mizahın sergilendiği iki farklı işe alım mülakatı, bir kadın ve bir erkek aday tarafından canlandırılmıştır. Oluşturulan dört durum (Başarılı mizah-kadın; başarılı mizah-erkek; başarısız mizah-kadın; başarısız mizah-erkek) dört ayrı kısa film olarak çekilmiş ve 255 psikoloji lisans öğrencisine izletilmiştir. İzlenen dört durumun, özgüven ve yeterlilik algıları açısından oluşturduğu farklar eşleştirilmiş örneklemler t-testi ile incelenmiştir. Algılanan özgüven açısından fark oluşmazken, başarılı mizah sergileyen kadın ve erkek adayın yeterlilik düzeyinin, başarısız mizah durumuna nazaran daha yüksek olarak algılandığ 1 belirlenmiştir. Başarılı mizah sergilenmesi durumunda, cinsiyetin anlamlı bir fark yaratmadığı, ancak başarısız mizah durumunda, erkek adayın yeterlilik düzeyinin kadın adaya nazaran daha düşük algılandı̆̆ı görülmüştür.

\section{A B S T R A C T}

The aim of this study is to investigate the effects of successful and unsuccessful humor in terms of self-confidence and competence perceptions. For this purpose, two different recruitment interviews, each with successful and unsuccessful humor and different genders were displayed. Four cases were watched by 255 psychology undergraduate students as four separate short films. Differences were examined by paired samples t-test. In terms of perceived self-confidence, there wasn't any difference; but the perceived competence level was significantly higher in case of succesful humor compared to the case of unsuccessful humor. In case of unsuccessful humor, there wasn't any difference in perceived self-esteem for both male and female candidate, but the competence of male candidate was perceived lower than the female candidate's competence.

\section{Giriş}

Mizahın, bireyin hem kendisiyle, hem de çevresiyle ilişkilerinde etkili olabilecek işlevleri bulunmaktadır. İş ortamında, çalışanlara sosyal ve psikolojik açıdan yarar sağlamakta (Duncan vd., 1990), zorlayıcı koşullar söz konusu olduğunda, mevcut durumun yükünü hafifletmek için imkan sunmaktadır. Mizahın en önemli fonksiyonu, sosyal etkileşimde üstlendiği roldür (Martin vd., 2003). Kişilerarası ilişkilerde önemli bir yer tutan mizah, aynı zamanda grup içinde duyguların yönetilmesine katkıda bulunmakta (Francis, 1994); grubun birliğini ve uyumunu desteklemektedir (Martin,

* Sorumlu yazar/Corresponding author

e-posta: z.oktug@iku.edu.tr 
2007). Bireylerin mizahı kullanma biçimleri, ilişkiler, bağlam, zamanlama gibi birçok faktöre bağlıdır. Kişisel özellikler de mizahın kullanım biçimi üzerinde etkili olmaktadır. Son yıllarda yapılan çalışmalar, mizahın kullanımında cinsiyetin de belirleyici olabileceğini göstermektedir. Erkekler cinsellik içeren ve saldırgan mizah tarzlarını tercih ederken, kadınlar sosyal ortamlarda gerilimi azaltma amaciyla mizahı kullanmayı tercih etmektedirler (Crawford ve Gressley, 1991). Bireyler tarafından yapılan şakalar da, bu tercihler çerçevesinde şekillenmektedir.

Günümüzün iş koşulları günden güne karmaşıklaşmakta, iş arama süreci de bireyleri zorlayabilmektedir. İşe alım sürecinin en önemli aşaması olan mülakat, gerek adayın kurum hakkında fikir edinmesi, gerekse işverenin adayın işe uygun olup olmadığını anlayabilmesi açısından belirleyici bir unsurdur (Berryman-Fink, 1989). İşe alım mülakatları farklı açılardan incelenmiş olsa da, bu süreçte mizahın kullanımının nasıl bir etki yaratabileceğine dair alan yazında herhangi bir çalışmaya rastlanmamıştır. Bu çalışmada işe alım sürecinde mizah kullanımının, özgüven ve yeterlilik algıları üzerinde yarattığı etkilerin incelenmesi hedeflenmiştir.

\subsection{Başarılı ve Başarısız Mizah}

Erken dönemdeki teoriler genellikle, mizahı oluşturan öğeleri incelemiş, ancak sonraki çalışmalar, içerik temelli tanımların, mizahın kullanım biçimlerini açıklamakta yetersiz kaldığını ortaya koymuştur (Ruch vd., 1993; Davis, 1993). Mizahın tanımlanmasında, şakayı yapan kişinin niyeti ve izleyenlerin buna tepkisi önemli bir yer tutmaktadır (Fine, 1983). Mizah, süreçteki üç aktörün, başka bir deyişle, şakayı yapanın, hedef alınan kişinin ve izleyicilerin etkileşimini içeren bir girişim olarak tanımlanmaktadır (Bitterly vd., 2016). Bitterly vd.'ne (2016) göre, mizahın başarısı, yapılan şakanın uygunluğuna ve izleyenlerin tepkisine bağlıdır. Başarılı mizah için, yalnızca komik olma durumu yeterli değildir; diğerlerinde tepki (gülme/gülümseme) oluşturabilmek de gereklidir (LehmanWillenbrock ve Allen, 2014). İş ortamında başarılı mizah vurgulandığında, çalışanda, gruplarda, örgütte, pozitif duygu ve düşünceler uyandıran, eğlendirici bir iletişimden söz edilmektedir (Romero ve Cruthirds, 2006). Başarısız mizah ise, rahatsız edici, negatif duygular uyandıran, izleyenlerin şakayı yapana dair değerlendirmelerine zarar veren bir girişim olarak tanımlanmaktadır (Bitterly vd., 2016). Gereğinden fazla yarar gözeten, sıkıcı ya da uygunsuz mizahi girişimler de başarısız olarak nitelendirilebilmektedir.

Mizahın, içinde bulunulan duruma uygun biçimde kullanılabilmesi bireysel özelliklerle ilişkili görünmektedir. Fiyaz vd. (2016), araştırmalarında uyumlu mizah tarzına sahip bireylerin, uyumsuz tarza sahip bireylere nazaran, daha yüksek düzeyde özsaygıya sahip olduklarını belirlemişlerdir. Edwardsa ve Martin (2014) yaptıkları çalışmada, mizahı uygun kullanabilen bireylerin psikolojik dayanıklılık düzeylerinin daha yüksek olduğunu, bunun yanında, uyumsuz mizah tarzlarının düşük düzeyde kontrol ve güven ile ilişkili olduğunu ortaya koymuşlardır. Bitterly vd. (2016) ise, başarılı ve başarısız mizahın etiklerini inceledikleri çalışmalarında, hem başarılı, hem başarısız mizahın, bireylerin "özgüven" düzeyinin daha yüksek olarak algılanmasına katkıda bulunduğunu; ancak, yalnızca başarılı mizahın, bireyin diğerleri tarafindan "yeterli" olarak algılanmasını sağladığını ortaya koymuşlardır. Başka bir deyişle, sergilenen mizah, başarılı da olsa, başarısız da olsa, özgüven düzeyinin diğerleri tarafından daha yüksek algılanmasına katkıda bulunmakta, ancak algılanan yeterlilik için aynı durum geçerli olmayıp, yalnızca başarılı mizah yeterlilik düzeyinin daha yüksek algılanmasını sağlamaktadır. Başarısız mizahın, özgüvenin yüksek algılanmasına olan katkısının, başarılı mizahla benzer biçimde olması ilgi çekici bir bulgu olarak görülmektedir. Ayrıca araştırmacılar aynı çalışmada, başarılı ve başarısız mizahı sergileyen bireyin cinsiyetinin de önem taşıyabileceğini belirterek, gelecekteki çalışmalarda cinsiyetin etkilerinin incelenmesi hususunda önerilerde bulunmuşlardır. Başarılı ya da başarısız mizahın, işe alım mülakatlarında kullanılmasının yaratabileceği etkilere dair alan yazında herhangi bir araştırmaya rastlanmamıştır.

\section{2. Özgüven ve Yeterlilik}

Bandura'ya (1997) göre özgüven, bireyin kendini değerli hissetme yargısıdır. Bireyin aldığı kararlara güvenmesi, herhangi bir faaliyetinde başarılı olacağına inanması özgüvenin varlığına işaret etmektedir (Feltz, 1988). Özgüven ve yeterlilik kavramları birbirini tamamlayıcı unsurlar olmakla birlikte, kapsamları birbirinden farklılaşmaktadır. Özgüven bireyin sahip olduğu güç, yetenek ve becerileri duyumsaması ile ortaya çıkarken, yeterlilik, bireyin sahip olduklarının değerlendirilmesini kapsamaktadır (Shrauger ve Schohn, 1995; Bandura 1997). Özgüven daha genel bir kavram olarak görülürken, yeterlilik alana özgü olarak değerlendirilebilmektedir (Bandura, 1995). Bireyin yeterlilik algıları farklı alanlarda elde ettiği sonuçlarla ilişkilidir. Bu bağlamda, alana özgü sonuçlar kapsamında değerlendirilebilir. Özgüven ise bireyin bütünlügünü ifade eden bir kavramdır. Bireyin tüm özelliklerine ilişkin genel bir kanaati içermektedir. Özgüveni yüksek olan bireylerin sosyal ortamlara daha kolay adapte olabildikleri ve risk alabildikleri görülmektedir (Anthony vd., 2007). Belirli bir alandaki yeterlilik inancı genel özgüven ile ilişkilidir (Wang ve Chang, 2018). Bunula birlikte, belirli bir alanda algilanan yeterlilik, özgüven algılarının da aynı düzeyde algılanmasına yol açmamaktadır. Başka bir deyişle, bireyin belirli bir alanda yeterli olarak algılanması, özgüven düzeyinin de yüksek olarak algılanmasını beraberinde getirmemektedir. Özgüven ve yeterlilik algılarının mizah kullanımı bağlamında birbirinden ayrıldığı noktalar da bu araştırma kapsamında irdelenmektedir. Çalışmanın alan yazında, iş yaşamında mizah kullanımına dair boşluğu doldurmaya katkı sağlamasının yanı sıra, özgüven ve yeterlilik algıları açısından da yararlı çıkarımlar sağlayabileceği düşünülmektedir.

\subsection{Mizah Kullanımı, Özgüven ve Yeterlilik Algıları}

Mizahın işe alım mülakatlarında kullanımına dair alan yazında yer alan bilgilerin oldukça kısıtlı olduğu gözlenmektedir. Adayların değerlendirilmesinde mizah kullanımının bir ölçüt olarak değerlendirilebileceğine dair bir bulguya rastlanmamıştır, ancak mizahın kişilerarası etkileşimdeki rolü bağlamında, mülakatlarda etkiye sahip olabileceği düşünülmektedir. İşe alım sürecinde, adayın iş için uygun olup olmadığının belirlenmesinde, özgüven ve yeterlilik önemli ölçütlerdir. Özgüven ve yeterlilik, bireyin performansı açısından önem taşımaktadır. Bireyin özgüveni ve yeterlilik algısı ile performansı arasında pozitif yönde ilişkiler bulunmaktadır (Chen vd., 2002). Bu bağlamda, özgüven ve yeterlilik, eleman seçiminde de rol oynayan etmenler olarak görülmektedir. İşe alım mülakatlarında adayın yeterli olarak 
algılanması, işe alım sürecindeki kararlarda etkili olmaktadır (Moore, 2017). Süreçte adayın mizahı başarılı ya da başarısız biçimde kullanması, özgüven ve yeterlilik düzeyinin ne şekilde algılandığını şekillendirebilmektedir. Bu noktadan hareketle, işe alım mülakatlarında adayın özgüven ve yeterlilik düzeyinin değerlendirilmesinde, başarılı ya da başarısız mizah sergilenmesinin anlamlı bir fark yaratabileceği düşünülmektedir. Bu çalışma kapsamında, yukarıdaki bilgi ve çıkarımlar 1şığında, aşağıdaki hipotezler oluşturulmuştur:

H1: Başarısız mizah sergileyen erkek adayın algılanan özgüven düzeyi ile başarılı mizah sergileyen erkek adayın algılanan özgüven düzeyi arasında anlamlı bir fark vardır.

H2: Başarısız mizah sergileyen erkek adayın algılanan yeterlilik düzeyi ile başarılı mizah sergileyen erkek adayın algılanan yeterlilik düzeyi arasında anlamlı bir fark vardır.

H3: Başarısız mizah sergileyen kadın adayın algılanan özgüven düzeyi ile başarılı mizah sergileyen kadın adayın algılanan özgüven düzeyi arasında anlamlı bir fark vardır.

H4: Başarısız mizah sergileyen kadın adayın algılanan yeterlilik düzeyi ile başarılı mizah sergileyen kadın adayın algılanan yeterlilik düzeyi arasında anlamlı bir fark vardır.

Mizahı sergileyen kişinin erkek ya da kadın olması, yapılan değerlendirmeler üzerinde etkili olabilmektedir (Crawford, 1995). Bitterly vd. (2016) mizahın izleyenler üzerindeki etkilerinin, cinsiyet açısından incelenmesinin önemini vurgulamışlardır. $\mathrm{Bu}$ bağlamda, mülakatta başarılı ya da başarısız mizah sergileyen adayın yarattığı etkide, cinsiyetinin de rol oynadığı öngörüsünden hareketle, aşağıdaki hipotezler oluşturulmuştur:

H5: Başarısız mizah sergileyen erkek adayın algılanan özgüven düzeyi ile başarısız mizah sergileyen kadın adayın algılanan özgüven düzeyi arasında anlamlı bir fark vardır.

H6: Başarısız mizah sergileyen erkek adayın algılanan yeterlilik düzeyi ile başarısız mizah sergileyen kadın adayın algılanan yeterlilik düzeyi arasında anlamlı bir fark vardır.

H7: Başarılı mizah sergileyen erkek adayın algılanan özgüven düzeyi ile başarılı mizah sergileyen kadın adayın algılanan özgüven düzeyi arasında anlamlı bir fark vardır.

H8: Başarılı mizah sergileyen erkek adayın algılanan yeterlilik düzeyi ile başarılı mizah sergileyen kadın adayın algılanan yeterlilik düzeyi arasında anlamlı bir fark vardır.

\section{Yöntem}

\section{1. Örneklem}

Araştırmanın örneklemini İstanbul'da bir vakıf Üniversitesinde öğrenim gören 255 Psikoloji Lisans öğrencisi (215 kadın, 40 erkek) oluşturmaktadır. Çalışmaya katılanların yaşları 17 ile 36 arasında $(\overline{\mathrm{x}}=20,25$; ss $=2,32)$ değiş̧mektedir.

\subsection{Veri Toplama Arac1 ve Uygulama}

Araştırma kapsamında öncelikle, Bitterly vd.'nin (2016) yaptıkları çalışmadan yola çıkarak, başarılı ve başarısız mizah tanımları yapılmış, mülakatçı ve aday arasında geçen diyaloglar belirlenmiş, araştırmacı tarafindan senaryo haline getirilmiştir. Tanımlar ve diyaloglar Ek 1'de verilmiştir.
Üniversitede görev yapan öğretim elemanları arasından seçilen gönüllüler tarafindan senaryo canlandırılmış ve üniversiteye ait stüdyoda çekim yapılmıştır. Bu sayede, dört farklı durumu içeren, dört kısa film oluşturulmuştur. 1. durumda, başarısız mizahın erkek aday tarafından sergilenmesi, 2. durumda, başarısız mizahın kadın aday tarafından sergilenmesi, 3. durumda, başarılı mizahın erkek aday tarafindan sergilenmesi, 4. durumda, başarılı mizahın kadın aday tarafından sergilenmesi canlandırılmıştır. Mülakatı gerçekleştiren kişi (erkek) her iki durumda da yansız bir duruş ve tonlama ile soruları yöneltmiş, ancak başarılı mizah sergilenmesi durumunda olumlu tepki (gülümseme, hoşnutluk, onaylama ifadesi) ile karşılık vermiş, başarısız mizah durumunda ise olumsuz tepki (kaşların çatılması, hoşnutsuzluk, geri çekilme) sergilemiştir. Dört durum, 255 Psikoloji lisans öğrencisi tarafından izlenmiş, her durumdan sonra (başarısız mizah-erkek; başarısız mizah-kadın; başarılı mizah-erkek; başarılı mizah-kadın) adayın özgüven ve yeterlilik düzeylerinin, 1'den 7'ye kadar uzanan bir çizelgede değerlendirilmesi istenmiştir. Katılımcılara dağıtılan değerlendirme formlarında, başarılı-başarısız mizahın tanımı ve kısa filmlerde izlemiş oldukları başarısız-başarılı mizah diyalogları yer almıştır. Katılımcıların izledikleri filmleri anladıklarını teyit etmek amacıyla, bu tanımları ve diyalogları okumaları, diyaloglardan hangisinin başarılı, hangisinin başarısız mizaha ait olduğunu belirtmeleri istenmiştir. Uygulama sonrasında, başarılı-başarısız mizah diyaloglarını, verilen tanımlar doğrultusunda doğru belirleyemeyen 5 katılımcının formu iptal edilmiş, 250 form analize dahil edilmiştir.

\section{Bulgular}

\subsection{Araştırma Değişkenlerine Ait Ortalama ve Standart Sapmalar}

Araştırma değişkenlerine ait ortalamalar ve standart sapmalar Tablo 1'de yer almaktadır. Buna göre, başarısız mizah sergileyen erkek adayın algılanan özgüven düzeyi $(\overline{\mathrm{x}}=5,65$, ss $=1,29)$, başarılı mizah sergileyen erkek adayın algılanan özgüven düzeyinden $(\overline{\mathrm{x}}=5,77$, ss $=1,25)$ daha düşüktür. Başarısız mizah sergileyen erkek adayın algılanan yeterlilik düzeyi $(\overline{\mathrm{x}}=4,10$, ss $=1,07)$, başarılı mizah sergileyen erkek adayın algılanan yeterlilik düzeyine $(\overline{\mathrm{x}}=5,60$, ss $=, 86)$ nazaran daha düşüktür. Başarısız mizah sergileyen kadın adayın algılanan özgüven düzeyi $(\overline{\mathrm{x}}=5,66$, ss $=1,25)$, başarılı mizah sergileyen kadın adayın algılanan özgüven düzeyinden $(\overline{\mathrm{x}}=5,76, \mathrm{ss}=1,16)$ daha düşüktür. Başarısız mizah sergileyen kadın adayın algılanan yeterlilik düzeyi $(\bar{x}=4,97$, ss $=, 91)$, başarılı mizah sergileyen kadın adayın algılanan yeterlilik düzeyine $(\overline{\mathrm{x}}=5,62$, ss $=1,20)$ nazaran daha düşüktür.

Tablo 1. Araştırma Değişkenlerine Ait Ortalama ve Standart Sapmalar $(\mathrm{n}=250)$

\begin{tabular}{cccccccccc}
\hline & \multicolumn{4}{c}{ Başarısız Mizah } & \multicolumn{4}{c}{ Başarılı Mizah } \\
\hline & \multicolumn{2}{c}{ Erkek } & \multicolumn{2}{c}{ Kadın } & \multicolumn{2}{c}{ Erkek } & \multicolumn{2}{c}{ Kadın } \\
\hline & $\overline{\mathrm{x}}$ & ss & $\overline{\mathrm{x}}$ & ss & $\overline{\mathrm{x}}$ & ss & $\overline{\mathrm{x}}$ & ss \\
\hline A.Ö & 5,65 & 1,29 & 5,66 & 1,25 & 5,77 & 1,25 & 5,76 & 1,16 \\
\hline A.Y & 4,10 & 1,07 & 4,97 &, 91 & 5,60 &, 86 & 5,62 & 1,20
\end{tabular}

A.Ö: Algılanan Özgüven; A.Y: Algılanan Yeterlilik 


\subsection{Hipotez Testleri}

Araştırmanın 1.,2.,3., ve 4. hipotezlerini test etmek üzere, erkek ve kadın adayın, özgüven ve yeterlilik düzeylerinin izleyenler tarafından değerlendirilmesinde, başarılı ya da başarısız mizah sergileme durumları arasında oluşabilecek farklar eşleştirilmiş örneklem t-testi analizleri ile incelenmiştir.

Birinci hipotezin test edilmesi için uygulanan analizin sonuçları Tablo 2'de yer almaktadır. Buna göre, erkek adayın, başarısız mizah sergilemesi durumunda izleyiciler tarafından algılanan özgüven düzeyi ile başarılı mizah sergilediği durumda algılanan özgüven düzeyi arasında anlamlı bir fark bulunmamaktadır $\quad(\mathrm{t}=-1,414 ; \mathrm{p}>.05)$. Birinci hipotez desteklenmemiştir.

Tablo 2. Başarısız ve Başarılı Mizah Sergileyen Erkek Adayın Algılanan Özgüven Düzeylerinin Karşılaştırılması ( $\mathrm{n}=250)$

\begin{tabular}{|c|c|c|c|c|}
\hline $\begin{array}{l}\text { Algilanan Özgüven } \\
\text { Erkek Aday }\end{array}$ & $\overline{\mathrm{x}}$ & ss & $\mathrm{t}$ & $\mathrm{p}$ \\
\hline Başarısız Mizah & 5,65 & 1,29 & \multirow{2}{*}{$-1,414$} & \multirow{2}{*}{,159 } \\
\hline Başarılı Mizah & 5,77 & 1,25 & & \\
\hline
\end{tabular}

Tablo 3'de ikinci hipotezin test edilmesi için uygulanan analiz sonuçları görülmektedir. Buna göre, erkek adayın, başarısız mizah sergilemesi durumunda izleyiciler tarafindan algilanan yeterlilik düzeyi ile başarılı mizah sergilediği durumda algılanan yeterlilik düzeyi arasında anlamlı bir fark vardır ( $\mathrm{t}=$ $-17,327 ; \mathrm{p}<.05)$. Başarılı mizah durumunda algılanan yeterlilik düzeyi daha yüksektir. İkinci hipotez desteklenmiştir.

Tablo 3. Başarısız ve Başarılı Mizah Sergileyen Erkek Adayın Algılanan Yeterlilik Düzeylerinin Karşılaştırılması $(n=250)$

\begin{tabular}{|c|c|c|c|c|}
\hline $\begin{array}{l}\text { Algilanan Yeterlilik } \\
\text { Erkek Aday }\end{array}$ & $\overline{\mathrm{x}}$ & Ss & $\mathrm{t}$ & $\mathrm{p}$ \\
\hline Başarısız Mizah & 4,10 & 1,07 & \multirow{2}{*}{$-17,327$} & \multirow{2}{*}{, 000} \\
\hline Başarılı Mizah & 5,60 & ,86 & & \\
\hline
\end{tabular}

Tablo 4'de üçüncü hipotezin test edilmesi için uygulanan analiz sonuçları görülmektedir. Buna göre, kadın adayın, başarısız mizah sergilemesi durumunda izleyiciler tarafından algılanan özgüven düzeyi ile başarılı mizah sergilediği durumda algılanan özgüven düzeyi arasında anlamlı bir fark bulunmamaktadır $\quad(\mathrm{t}=-1,002 ; \quad \mathrm{p}>.05)$. Üçüncü hipotez desteklenmemiştir.

Tablo 4. Başarısız ve Başarılı Mizah Sergileyen Kadın Adayın Algılanan Özgüven Düzeylerinin Karşılaştırılması $(n=250)$

\begin{tabular}{|c|c|c|c|c|}
\hline $\begin{array}{l}\text { Algilanan Özgüven } \\
\text { Kadın Aday }\end{array}$ & $\overline{\mathrm{x}}$ & ss & $\mathrm{t}$ & $\mathrm{p}$ \\
\hline Başarısız Mizah & 5,66 & 1,25 & \multirow[b]{2}{*}{$-1,002$} & \\
\hline Başarılı Mizah & 5,76 & 1,16 & & ,317 \\
\hline
\end{tabular}

Tablo 5'de dördüncü hipotezin test edilmesi için uygulanan analiz sonuçları görülmektedir. Buna göre, kadın adayın, başarısız mizah sergilemesi durumunda izleyiciler tarafından algılanan yeterlilik düzeyi ile başarılı mizah sergilediği durumda algılanan yeterlilik düzeyi arasında anlamlı bir fark vardır $(\mathrm{t}=-7,923 ; \mathrm{p}<.05)$. Başarılı mizah durumunda algılanan yeterlilik düzeyi daha yüksektir. Dördüncü hipotez desteklenmiştir.

Tablo 5. Başarısız ve Başarılı Mizah Sergileyen Kadın Adayın Algılanan Yeterlilik Düzeylerinin Karşılaştırılması ( $\mathrm{n}=250)$

\begin{tabular}{lllll}
\hline $\begin{array}{l}\text { Algılanan Yeterlilik } \\
\text { Kadın Aday }\end{array}$ & $\overline{\mathrm{x}}$ & $\mathrm{ss}$ & $\mathrm{t}$ & $\mathrm{p}$ \\
\cline { 1 - 3 } Başarısız Mizah & 4,97 &, 91 & & \\
\cline { 1 - 4 } Başarılı Mizah & 5,62 & 1,20 & &, 000 \\
\hline
\end{tabular}

Araştırmanın 5.,6.,7., ve 8. hipotezlerini test etmek üzere, adayların başarılı ve başarısız mizah sergilemeleri durumunda, özgüven ve yeterlilik düzeylerinin izleyenler tarafindan değerlendirilmesinde, adayın cinsiyetinin oluşturabileceği farklar, eşleştirilmiş örneklem t-testi analizleri ile incelenmiştir.

Beşinci hipotezin test edilmesi için uygulanan analizin sonuçları Tablo 6'da yer almaktadır. Buna göre, başarısız mizah sergilenmesi durumunda, kadın aday ile erkek adayın algılanan özgüven düzeyleri arasında anlamlı bir fark bulunmamaktadır $(\mathrm{t}=-, 123 ; \mathrm{p}>.05)$. Beşinci hipotez desteklenmemiştir.

Tablo 6. Erkek ve Kadın Adayın Başarısız Mizah Sergilemeleri Durumunda Algılanan Özgüven Düzeylerinin Karşılaştırılması $(\mathrm{n}=250)$

\begin{tabular}{lllll}
\hline $\begin{array}{l}\text { Algılanan Özgüven } \\
\text { Başarısız Mizah }\end{array}$ & $\overline{\mathrm{x}}$ & $\mathrm{ss}$ & $\mathrm{t}$ & $\mathrm{p}$ \\
\cline { 1 - 2 } Erkek & 5,65 & 1,29 & & \\
\hline Kadın & 5,66 & 1,25 & &, 902 \\
\hline
\end{tabular}

Tablo 7'de altıncı hipotezin test edilmesi için uygulanan analiz sonuçları görülmektedir. Buna göre, başarısız mizah sergilenmesi durumunda, kadın aday ile erkek adayın algılanan yeterlilik düzeyleri arasında anlamlı bir fark vardır $(\mathrm{t}=-9,790 ; \mathrm{p}<.05)$. Kadın adayın algılanan yeterlilik düzeyi daha yüksektir. Altıncı hipotez desteklenmiştir.

Tablo 7. Erkek ve Kadın Adayın Başarısız Mizah Sergilemeleri Durumunda Algılanan Yeterlilik Düzeylerinin Karşılaştırılması $(n=250)$

\begin{tabular}{|c|c|c|c|c|}
\hline $\begin{array}{l}\text { Algılanan Yeterlilik } \\
\text { Başarısız Mizah }\end{array}$ & $\overline{\mathrm{x}}$ & SS & $\mathrm{t}$ & $\mathrm{p}$ \\
\hline Erkek & 4,10 & 1,29 & \multirow{2}{*}{$-9,790$} & \multirow{2}{*}{,000 } \\
\hline Kadın & 4,97 & 1,25 & & \\
\hline
\end{tabular}

Tablo 8'de yedinci hipotezin test edilmesi için uygulanan analiz sonuçları görülmektedir. Buna göre, başarılı mizah sergilenmesi durumunda, kadın aday ile erkek adayın algılanan özgüven düzeyleri arasında anlamlı bir fark bulunmamaktadır $\quad(\mathrm{t}=, 150 ; \quad \mathrm{p}>.05)$. Yedinci hipotez desteklenmemiştir. 
Tablo 8. Erkek ve Kadın Adayın Başarılı Mizah Sergilemeleri Durumunda Algılanan Özgüven Düzeylerinin Karşılaştırılması $(\mathrm{n}=250)$

\begin{tabular}{|c|c|c|c|c|}
\hline $\begin{array}{l}\text { Algılanan Özgüven } \\
\text { Başarısız Mizah }\end{array}$ & $\overline{\mathrm{x}}$ & SS & $\mathrm{t}$ & $\mathrm{p}$ \\
\hline Erkek & 5,77 & 1,25 & \multirow{2}{*}{, 150} & \multirow{2}{*}{,881 } \\
\hline Kadın & 5,76 & 1,16 & & \\
\hline
\end{tabular}

Tablo 9'da sekizinci hipotezin test edilmesi için uygulanan analiz sonuçları görülmektedir. Buna göre, başarılı mizah sergilenmesi durumunda, kadın aday ile erkek adayın algılanan yeterlilik düzeyleri arasında anlamlı bir fark bulunmamaktadır $\quad(\mathrm{t}=-, 172 ; \quad \mathrm{p}>.05)$. Sekizinci hipotez desteklenmemiştir.

Tablo 9. Erkek ve Kadın Adayın Başarılı Mizah Sergilemeleri Durumunda Algılanan Yeterlilik Düzeylerinin Karşılaştırılması $(n=250)$

\begin{tabular}{|c|c|c|c|c|}
\hline $\begin{array}{l}\text { Algılanan Yeterlilik } \\
\text { Başarısız Mizah }\end{array}$ & $\overline{\mathrm{x}}$ & ss & $\mathrm{t}$ & $\mathrm{p}$ \\
\hline Erkek & 5,60 & ,86 & \multirow{2}{*}{,- 172} & \multirow{2}{*}{,863 } \\
\hline Kadın & 5,62 & 1,20 & & \\
\hline
\end{tabular}

\section{Sonuc}

$\mathrm{Bu}$ çalışmada, başarılı ve başarısız mizah kullanımının, algılanan özgüven ve yeterlilik düzeyleri üzerindeki etkilerinin araştırılması hedeflenmiştir. Mizahın başarılı ve başarısız olarak sergilenmesi, hedefteki kişinin tepkileri temel alınarak tanımlanmıştır. $\mathrm{Bu}$ bağlamda oluşturulan mülakatlarda, izleyenlerin adayı değerlendirmelerindeki farklılıklar incelenmiştir. Ayrıca başarılı ve başarısız mizah sergilenmesi durumlarında, adayın cinsiyetinin etkisi, algılanan özgüven ve yeterlilik çerçevesinde değerlendirilmiştir. Elde edilen bulgular, başarılı mizah sergilenmesi durumunda, başarısız mizah durumuna nazaran, hem kadın, hem erkek adayın yeterlilik düzeylerinin daha yüksek olarak algılandığını göstermektedir. Ancak, algılanan özgüven söz konusu olduğunda, hem kadın, hem erkek adayda, başarılı ya da başarısız mizah sergilenmesi arasında anlamlı bir fark oluşmamaktadır. Başka bir deyişle, başarılı mizah sergilediğinde kişi, başarısız mizah sergileyene nazaran, daha yeterli olarak algılanmakta; ancak özgüveni açısından değerlendirildiğinde, başarılı ya da başarısız mizah sergilemesi anlamlı bir fark yaratmamaktadır. Bu bulgu, Bitterly vd.'nin (2016) çalışmalarında ortaya koydukları, başarılı mizahın bireyin diğerleri tarafından yeterli olarak algılanmasına katkı sağladığı bulgusu ile tutarlıdır.

Araştırmanın ilgi çekici bir bulgusu da, başarısız mizah sergilenmesi durumunda, kadın adayın yeterlilik düzeyinin, erkek adayın yeterlilik düzeyine nazaran, anlamlı biçimde daha yüksek olarak algılanmasıdır. Başarılı mizah sergilenmesi durumunda, kadın ve erkek aday arasında anlamlı bir farkın görülmemektedir. Algılanan özgüven açısından değerlendirildiğinde, hem başarılı hem başarısız mizah sergilenmesi durumlarında, kadın ile erkek arasında anlamlı bir fark oluşmamaktadır. Başka bir deyişle, cinsiyet açısından değerlendirildiğinde fark gözlenen tek durum, başarısız mizah sergileyen kadın adayın, başarısız mizah sergileyen erkek adaya nazaran daha yeterli olarak algılanmasıdır. Bu noktadan hareketle, başarısız mizah kullanımının, algılanan yeterlilik düzeyi açısından, erkek adayda, kadın adaya nazaran daha olumsuz bir etki oluşturduğu söylenebilir.

Mizah kullanımının mülakatlarda ne şekilde değerlendirilebileceğine dair alan yazında kısıtlı bilgiye rastlanmaktadır. Mizah kullanımı genel olarak, olumlu duygu durumunda artış, streste azalma, genel psikolojik sağlıkta ve kendilik algısında iyileşme ile ilişkilendirilmektedir (Martin ve Lefcourt, 1983; Kuiper ve Martin, 1993; Newman ve Stone, 1996; Thorson vd., 1997). İşe alım mülakatlarında ise, görüşmeyi yapan ve değerlendirilen kişi açısından ayrı ayrı bakıldığında, adayın görüşme sürecini yönetme çabası ve bu amaçla mizahı sergilemesi önemli bir nokta olarak görülebilir. Mizah, duyguların yönetilmesinde bir araç olarak da görülmektedir (Mathews, 2016). Adayın mülakatta sergilediği mizahın, süreç yönetiminin yanı sıra, kendi duygularını yönetme çabasından da doğabileceği düşünülebilir. İzleyenler açısından bakıldığında, adayın sergilediği mizah özgüven ve yeterlilik algılarını etkileyebilmektedir. Bu bağlamda, mizahın yeterlilik ve özgüven ile ilişkileri önemli görülmektedir. Palmer (2010) öğretmenlerin mizah anlayışları ile yeterlilik algıları arasındaki ilişkiyi incelediği çalışmasında, öğretmenlerin olayların gülünç yönünü görebilme, mizah yoluyla başa çıkabilme becerileri arttıkça, öz-yeterlilik algılarının da arttığını ortaya koymuştur. $\mathrm{Bu}$ çalışmada izleyenlerin değerlendirmeleri adayın öz-yeterlilik algıları kapsamında değerlendirildiğinde, başarılı mizah sergilemesi durumunda adayın öz-yeterlilik algılarındaki artışın, izleyenler tarafından da benzer yönde değerlendirilebileceği sonucuna varılmaktadır. Fiyaz vd. (2016) ise, ruh sağlığı uzmanlarının mizah tarzlarını inceledikleri çalışmada, uyumlu mizah tarzı sergileyenlerin özgüvenlerinin, uyumsuz mizah tarzı sergileyenlere nazaran daha yüksek düzeyde olduğunu ortaya koymuşlardır. $\mathrm{Bu}$ araştırmada elde edilen bulgular, başarılı mizah sergileyenlerin özgüven düzeylerinin izleyenler tarafindan algılanmasında, başarısız mizaha nazaran anlamlı bir fark oluşmadı ğına işaret etmektedir. Yeterlilik, bireyin belli konularda başarılı olacağına dair inancını kapsadığından (Bandura, 1986), sergilenen mizahın hedef üzerinde oluşturduğu başarılı etki, izleyen açısından, bireyin yeterliliğine katkı sağlayan bir öğe olarak algılanmaktadır. Özgüven ise, yeterlilik kavramından farklılaşmakta, belli bir alana özgü olarak değil, daha genel bir olgu olarak görülmektedir (Bandura, 1995). Bireyin kendini değerli hissetmesini de kapsayan özgüven kavramı, yeterliliğe nazaran, bireyin başarısı ile daha dolaylı bir ilişkiye sahip görünmektedir. Bu noktadan hareketle, özgüven kapsamında değerlendirildiğinde, yeterlilik kapsamındaki değerlendirmeye nazaran, kullanılan mizahın daha zayıf bir etki oluşturduğu ve bu bağlamda, adayın başarısız ya da başarılı oluşunun anlamlı bir fark yaratmadığı düşünülebilir. Bulgular, mülakatlarda mizah kullanımının, algılanan yeterlilik bağlamında değerlendirilebileceğine işaret etmektedir.

\section{5. Öneriler}

Çalışma kapsamında, mizahın işe alım sürecindeki etkileri incelenmiş, bu çerçevede, özgüven ve yeterlilik algılarına katkısı bağlamında farklılıklar tespit edilmiştir. Ulaşılan sonuçlar, mizahın uygun kullanımının bireyin yeterliliğine katkı sağladığını göstermekte, bu bağlamda, işe alım mülakatlarında adaya sağlayabileceği yararlar önem arz etmektedir. Bulgular, erkek adayların kadın adaylara nazaran, 
mizahın uygun kullanılmaması durumunda daha olumsuz sonuçlarla karşılaşabileceğine dair ipuçları sunmaktadır. Bu noktadan hareketle, erkek adayların işe alım mülakatlarında mizah kullanımı hususunda kadın adaylara nazaran olumsuz algılanma riskine daha açık oldukları söylenebilir. Diğer yandan, başarısız mizahın taşıdığı risklere rağmen, günümüz iş yaşamındaki rekabet göz önüne alındığında, mizah kullanımının olumlu yönde bir fark yaratabileceği hususu dikkate değer görülmektedir.

Mizah, son yıllarda, hem bireyin ruh sağlığına, hem de sosyal ortamların iyileştirilmesine katkıları açısından araştırmacıların ilgisini çekmektedir. Araştırma bulguları, mizahın yaşamının farklı alanlarında kullanılması sonucu ortaya çıkabilecek olumlu ve olumsuz etkilerin daha ayrıntılı irdelenmesi açısından önem taşımaktadır. Çalışmanın, mizahın mülakatlarda başarılı ya da başarısız biçimde kullanılmasının sonuçlarına dair alan yazındaki boşluğu doldurmaya katkı sağladığı düşünülmektedir. İşe alım mülakatlarında mizahın, bireyler arasındaki etkileşimin şekillenmesinde nasıl bir rol oynadığının araştırılmaya devam edilmesi, mizah çalışmalarına da katkı sağlayacaktır. Bu çalışmada mülakatı yapan kişi, tek bir cinsiyet ile değerlendirilmiştir. Gelecekteki çalışmalarda, mülakatı yapan kişi ile aday arasındaki etkileşimde, farklı ya da aynı cinsiyetlere sahip olmaları durumunda oluşabilecek farkların incelenmesinin yararlı olacağı düşünülmektedir.

\section{Teşekkür}

Üniversite kadrosunun değerli mensuplarından Can Ertan'a, Sezer Ağgez'e ve Serpil Şenol'a film çekimi sürecinde verdikleri katkı ve destekten dolayı teşekkürlerimi sunarım.

\section{Kaynakça}

Anthony, D. B., Wood, J. V., Holmes, J. G. (2007). Testing sociometer theory: Self-esteem and the importance of acceptance for social decision-making. Journal of Experimental Social Psychology, 43, 425-432.

Bandura, A. (1986). Social Foundations of Thought and Action: A Social Cognitive Theory. Englewood Cliffs, NJ: Prentice Hall.

Bandura, A. (1995). Exercise of Personel and Collective Efficacy in Changing Socities. Self-Efficacy in Changing Socities. A. Bandura (Ed). New York: Cambridge University Press.

Bandura, A., (1997). Self-efficacy: The Exercise of Control, New York: Freeman.

Berryman-Fink, C. (1989). The manager's desk reference. New York: Amacom

Bitterly, T. B., Brooks, A. W. \& Schweitzer, M. E. (2016). Risky Business: When Humor Increases and Decreases Status. Journal of Personality and Social Psychology, Advance online publication. Erişim Aralık 2017, http://dx.doi.org/10.1037/pspi0000079

Chen, G., Bliese, P.D., Payne, S.C., Zaccaro, S.J., Simsarian W.S., Mathieu, J.E. \& Born, D.H. (2002). Simultaneous Examination of the Antecedents and Consequences of
Efficacy Beliefs at Multiple Levels of Analysis. Human Performance, 15(4), 381-409.

Crawford, M. \& Gressley, D. (1991). Creativity, Caring and Context - Women's and Men's Accounts of Humor Preferences and Practices. Psychology of Women Quarterly, 15(2), 217-231.

Crawford, M. (1995). Talking Difference: On Gender and Language. Sage Publications.

Davis, M.S. (1993). What's So Funny? Chicago: University of Chicago Press.

Duncan, W.J., Smeltzer, L.R. \& Leap, T.L. (1990). Humor and Work: Applications of Joking Behavior to Management. Journal of Management, 16(2), 255-278.

Edwardsa K.R. \& Martin, R.A. (2014). The Conceptualization, Measurement, and Role of Humor as a Character Strength in Positive Psychology. Europe's Journal of Psychology, 10(3), 505-519.

Feltz, D. L., (1988). Self Confidence and Sport Performance, Exercise and Sports Science Reviews, 16, 423-458.

Fine, G. A. (1983). Sociological Approaches to the Study of Humor. Handbook of Humor Research Vol 1: Basic Issues. Ed. Paul E. McGhee and Jeffrey H. Goldstein. Springer.

Fiyaz, K., Majeed, S. \& Khan, A.Q. (2016). Impact of Styles of Humor and Self Esteem on Psychological Wellbeing of Mental Health Professionals. The Journal of Pakistan Psychiatric Society, 13(2), 12-17.

Francis, L.E. (1994). Laughter, the Best Mediation: Humor as Emotion Management in Interaction. Symbolic Interaction, 17, 47-63.

Kuiper, N. A., Martin, R. A. \& Olinger, L. J. (1993). Coping Humour, Stress, and Cognitive Appraisals. Canadian Journal of Behavioural Science, 25, 81-96.

Lehmann-Willenbrock, N. \& Allen, J. A. (2014). How Fun Are Your Meetings? Investigating The Relationship Between Humor Patterns In Team Interactions and Team Performance. Journal of Applied Psychology, 99, 12781287.

Mathews, L. (2016). Role of Humor in Emotion Regulation: Differential Effects of Adaptive and Maladaptive Forms of Humor. Unpublished Dissertation. New York: The Graduate Center, City University of New York. ErişimAralık2017, http://academicworks.cuny.edu/gc_etds/1507.

Martin, R. A. (2007). The Psychology of Humor: An Integrative Approach. Waltham MA: University of Western Australia Academic Press.

Martin, R. A. \& Lefcourt, H. M. (1983). Sense of Humor as a Moderator of the Relation between Stressors and Moods. Journal of Personality and Social Psychology, 6, 13131324.

Martin, R. A., Puhlik-Doris, P., Larsen, G., Gray, J. \& Weir, K. (2003). Individual Differences in Uses of Humor and Their Relation To Psychological Well-Being: Development of The Humor Styles Questionnaire. Journal of Research in Personality, 37, 48-75. 
Moore, D.A. (2017). How to Improve the Accuracy and Reduce the Cost of Personnel Selection. California Management Review, 60(1), 8-17.

Newman, M. G. \& Stone, A. A. (1996). Does Humor Moderate the Effects of Experimentally Induced Stress? Annuals of Behavioral Medicine, 18(2), 101-109.

Palmer, T.E. (2010). The Potency of Humor and Instructional Self-Efficacy on Art Teacher Stress. Studies in Art Education, 52(1), 69-83.

Romero, E. J. \& Cruthirds, K. W. (2006). The Use of Humor in The Workplace. Academy of Management Perspectives, 20, 58 - 69.

Ruch, W., Attardo S. \& Raskin, V. (1993). Toward an Empirical Verification of the General Theory of Humor. Humor, 6, 123-136.

Shrauger, J. S. ve Schohn, M. (1995). Self-confidence in college students: Conceptualization, measurement, and behavioral implications. Assessment, 2(3), 255-278.

Thorson, J. A., Powell, F. C., Sarmany-Schuller, I. \& Hampes, W. P. (1997). Psychological Health and Sense of Humor. Journal of Clinical Psychology, 53(6), 605-619.

Wang, Y. ve Chang, Y. (2018). How specific and general selfconfidence affect assortment decisions.Social Behavior and Personality: An international journal, 46, 1687-1696.

\section{Ek 1.}

\section{Tanımlar}

Başarısız Mizah: Uygunsuz içeriği sebebiyle, karşı tarafta olumsuz duygu ya da tepki (örneğin; kaşların çatılması, geri çekilme...) oluşturan bir girişimdir.
Başarılı Mizah: Yalnızca eğlendirme amacıyla değil, aynı zamanda karşı tarafta olumlu bir duygu ya da tepki (örneğin; gülme, gülümseme...) oluşturmak üzere bulunulan bir girişimdir.

Diyaloglar

\section{Durum-1}

Mülakatçı: İşe alım sürecinde adaylarımızı mümkün olduğunca tanımaya çalışıyoruz. Bu yüzden size birkaç soru daha soracağım... 5 yıl sonra kendinizi nerede görüyorsunuz..?

Aday: Genel müdürün ayağını kaydırmış olarak görüyorum... (Güler, devam eder) Alana yeterince hakim olmuş ve yeni bir müşteri portföyü oluşturmuş olarak görüyorum...

Mülakatçının kaşları çatılır, hoşnutsuz bir ifadeyle geri çekilir.

\section{Durum-2}

Mülakatçı: İşe alım sürecinde adaylarımızı mümkün olduğunca tanımaya çalışıyoruz. $\mathrm{Bu}$ yüzden size birkaç soru daha soracağım... 5 yil sonra kendinizi nerede görüyorsunuz..?

Aday: Sizlerle birlikte bu soruyu soruşunuzun beşinci yılını kutlarken görüyorum... (Güler, devam eder) Alana yeterince hakim olmuş ve yeni bir müşteri portföyü oluşturmuş olarak görüyorum...

Mülakatçı gülümser, hoşnut bir ifadeyle adaya bakar. 

